\title{
Pengaruh Edukasi melalui Media Audio Visual terhadap Pengetahuan dan Sikap Remaja Overweight
}

\author{
Risma Meidiana ${ }^{1}$, Demsa Simbolon ${ }^{2}$, Anang Wahyudi ${ }^{3}$ \\ 1,2,3 Jurusan Gizi, Politeknik Kesehatan Kemenkes Bengkulu, Indonesia \\ Email: rismameidiana03@gmail.com
}

\begin{abstract}
Audio-Visual Media Education Effect to Knowledge and Attitudes of Adolescents Overweight. One of the nutritional problems that occur is overweight. The level of knowledge nutrition in an adolescent is one of the factors that can affect the occurrence of obesity in adolescents. Most occurrences of nutritional problems are more or less avoidable if adolescents have sufficient knowledge and attitudes about maintaining nutrition and managing food. This research was a quasi-experimental study with a pre-post test with control group design. The subjects of this study were overweight adolescents totaling 40 people, the intervention group received education through audiovisual media while the control group with leaflets. The results showed the average value of knowledge and attitudes of adolescents after and before being given education for Leaflet groups were the average value of knowledge before 8.60 and after 9.48, attitudes value before 36.58 and after 40.38. While audiovisual media groups, the average value of knowledge before 8.83 and after 9.42 , values for attitudes before 36.45 and after 39.65 . There was an influence of education by using audiovisual media and leaflets to increase the knowledge and attitudes of overweight adolescents. Suggestions for schools to be able to use audiovisual media and leaflets as a medium to educate nutrition about students in schools so that they can apply daily life and remind each other to lose weight and live healthy lives.
\end{abstract}

Keywords: Adolescents, Attitude, Education, Knowledge, Overweight

\begin{abstract}
Abstrak: Pengaruh Edukasi melalui Media Audio Visual terhadap Pengetahuan dan Sikap Remaja Overweight. Salah satu masalah gizi yang terjadi yaitu kelebihan berat badan (overweight). Tingkat pengetahuan gizi remaja merupakan salah satu faktor yang dapat mempengaruhi terjadinya obesitas pada remaja. Sebagian besar kejadian masalah gizi lebih atau kurang dapat dihindari apabila remaja mempunyai ilmu pengetahuan dan sikap yang cukup tentang memelihara gizi dan mengatur makan. Jenis penelitian quasy experimental dengan rancangan prepost test with control group design. Subjek penelitian remaja overweight yang berjumlah 40 orang, kelompok intervensi mendapat edukasi melalui media audio visual sedangkan kelompok kontrol dengan leaflet. Hasil penelitian menunjukkan rata-rata nilai pengetahuan dan sikap remaja sesudah dan sebelum diberikan edukasi untuk kelompok Leaflet nilai rata-rata pengetahuan sebelum 8,60 dan sesudah 9,48 nilai untuk sikap sebelum 36,58 dan sesudah 40,38 sedangkan kelompok video pengetahuan sebelum 8,83 dan sesudah 9,42 untuk sikap sebelum 36,45 dan sesudah 39,65. Ada pengaruh edukasi dengan menggunakan media audio visual dan leaflet terhadap peningkatan pengetahuan dan sikap remaja overweight. Saran bagi pihak sekolah agar dapat menggunakan media audio visual dan leaflet sebagai media untuk melakukan edukasi mengenai gizi kepada siswa-siswi yang ada di sekolah, agar mereka dapat mengaplikasikan dikehidupan sehari-hari dan saling mengingatkan sesama teman agar menurunkan berat badan serta hidup sehat.
\end{abstract}

Kata kunci: Remaja, Sikap, Edukasi, Pengetahuan, Overweight

Kelebihan berat badan atau Obesitas dapat diartikan sebagai penimbunan jaringan lemak tubuh secara berlebihan yang memberi efek buruk pada kesehatan. Kondisi ini dapat di alami oleh setiap golongan umur baik laki-laki maupun perempuan, akan tetapi remaja dan dewasa merupakan kelompok yang paling sering mengalaminya (Kussoy, 2013).
Kelebihan berat badan pada remaja penting untuk diperhatikan karena remaja yang mengalami kelebihan berat badan $80 \%$ berpeluang untuk mengalami kelebihan berat badan pula pada saat dewasa. Selain itu, terjadi peningkatan remaja kelebihan berat badan yang di diagnosis dengan kondisi penyakit yang biasa dialami orang dewasa, seperti diabetes tipe 2 dan hipertensi (Safitri dan Fitranti, 2016 ). 
Remaja adalah masa transisi dalam periode anak ke periode dewasa yang sebagian besar menganggap diri mereka sehat walaupun sebenarnya mengalami masalah gizi. Salah satu masalah gizi yang terjadi yaitu kelebihan berat badan (overweight). Overweight yaitu kondisi dimana tubuh mengalami penumpukan lemak berlebih yang ditandai dengan z-score (IMT/U) $>1$ SD - 2 SD (Safitri dan Fitranti, 2016 ).

Gaya hidup remaja saat ini yang sering melewatkan sarapan dan lebih suka mengkonsumsi fast food serta cenderung sedentary life style, membuat remaja berisiko untuk menderita obesitas (Kussoy, 2013).

Prevalensi obesitas telah meningkat di seluruh dunia World Health Organization (WHO) memperkirakan bahwa pada tahun 2005 terdapat 1,5 miliar orang dewasa (berusia di atas 15 tahun) kelebihan berat badan dan 400 juta orang obesitas. Berdasarkan tren di seluruh dunia sekarang ini, WHO memperkirakan akan ada 2,3 miliar orang dewasa kelebihan berat badan dan 700 juta orang obesitas di tahun 2015 (WHO, 2006).

Menurut hasil Riskesdas tahun 2010 prevalensi kegemukan dan obesitas pada remaja (13-15 tahun) sebesar 2,5\%. Sedangkan pada tahun 2013 prevalensi gemuk pada remaja (1315 tahun) sebanyak 3,8\% (Riskesdas, 2013). Survei awal yang dilakukan di SMP 04 kota Bengkulu diperoleh data berat badan berlebih sebanyak 5 orang dari 10 siswa yaitu $50 \%$.

Faktor risiko terhadap kelebihan berat badan atau obesitas jika tidak diupayakan perbaikannya akan mempengaruhi kualitas masyarakat di masa mendatang, gambaran status gizi dan pengetahuan di masa sekarang berdampak besar pada gambaran status gizi di masa mendatang, sehingga perlu dicari informasi mengenai faktor-faktor risiko terhadap kelebihan berat badan, khususnya faktor-faktor risiko yang banyak muncul pada remaja (Hendra dkk, 2016).

Berdasarkan hasil penelitian Widianti Ali pada tahun 2017 dari 30 responden obesitas didapati bahwa, 26 responden $(86,7 \%)$ memiliki kualitas tidur buruk. Dampak yang ditimbulkan akibat obesitas adalah dapat menyebabkan gangguan pernafasan sleep apnea, diabetes melitus, panyakit kardiovaskuler, hipertensi. Sleep apnea yang ditandai dengan mendengkur dan kantuk berlebih merupakan gangguan tidur yang paling berbahaya saat ini sehingga dapat mempengaruhi kualitas tidur anak pada usia remaja (Ali, 2017).

Hasil penelitian Suryaputra (2012) menemukan bahwa tingkat pengetahuan gizi remaja merupakan salah satu faktor yang dapat mempengaruhi terjadinya obesitas pada remaja. Kurangnya pengetahuan gizi pada sebagian besar remaja obesitas memungkinkan mereka kurang dapat memilih menu makanan yang bergizi. Sebagian besar kejadian masalah gizi lebih atau kurang dapat dihindari apabila remaja mempunyai ilmu pengetahuan yang cukup tentang memelihara gizi dan mengatur makan.

Upaya peningkatan pengetahuan pada remaja diperlukan suatu media pembelajaran yang dapat menggambarkan konsep fisik secara nyata. Salah satu media yang dapat di gunakaan adalah video. Video merupakan media audio visual yang dapat mengungkapkan objek dan peristiwa seperti keadaan sesungguhnya. Melalui media video, siswa mampu memahami pesan pembelajaran secara lebih bermakna sehingga informasi yang disampaikan melalui video tersebut dapat dipahami secara utuh (Primavera dan Suwarna, 2014).

Pelaksanaan proses pembelajaran, media pengajaran merupakan wadah dan penyalur pesan dari sumber pesan (guru), kepada penerima pesan (siswa). Dalam batasan yang lebih luas, media pengajaran sebagai segala sesuatu yang dapat digunakan untuk merangsang pikiran, perasaan, perhatian, dan kemauan siswa sehingga mendorong terjadinya proses belajar pada diri siswa (Mahnun, 2012).

Menurut hasil penelitian Oktira tahun 2013, media audio-visual telah berhasil membangkitkan ketertarikan siswa untuk mempelajari seni budaya. Rasa ketertarikan telah membangkit rasa kemandirian siswa itu sehingga partisipasi aktif siswa dalam proses pembelajaran juga meningkat dengan sendirinya. Cara membangkitkan kemandirian adalah dengan menggunakan media audio visual sebagai alat penunjang kemandirian siswa terhadap pembelajaran seni budaya. Peningkatan partisipasi aktif siswa dalam proses pembelajaran sebagaimana terlihat beberapa indikator seperti keinginan, perhatian dan partisipasi setelah mengunakan media audio visual mengindikasikan telah terbangkitnya motivasi siswa dalam belajar (Oktira dkk, 2013).

Perubahan pengetahuan, sikap, perilaku dan gaya hidup, pola makan, serta peningkatan pendapatan mempengaruhi pemilihan berbagai jenis dan jumlah makanan yang dikonsumsi. Hasil penelitian dari Harikedua dan Tando 2012 menunjukkan bahwa terjadinya obesitas sentral sangat berhubungan dengan asupan makanan berisiko, yaitu tingginya asupan protein, lemak, natrium dan rendahnya asupan kalium dan serat (Harikedua dan Tando, 2012). 
Tujuan penelitian ini adalah untuk mengetahui pengaruh edukasi pendidikan remaja overweight dan obesitas melalui media audio visual terhadap pengetahuan dan sikap remaja.

\section{METODE}

Penelitian ini merupakan penelitian quasy experimental dengan rancangan pre-post test group design. Penelitian ini menggambarkan perbandingan antara 2 kelompok perlakuan. Populasi target dalam penelitian ini adalah remaja overweight di SMP Negeri 04 Kota Bengkulu dan SMP IT IQRA' Bengkulu. Populasi terjangkau pada penelitian ini adalah siswa overweight usia 12-15 tahun di SMP Negeri 04 Kota Bengkulu dan SMP IT IQRA' Bengkulu. Penelitian ini di lakukan dengan melakukan observasi pertama (pretest) sebelum di berikan edukasi gizi dan setelah dilakukan observasi kembali (post-test) untuk melihat hasil atau pengaruh dari intervensi yang diberikan. Data pengetahuan dan sikap gizi diperoleh dari pengisian kuesioner sebelum dan setelah edukasi. Total sampel sebanyak 40 subjek di setiap kelompok perlakuan yang dipilih secara purposive sampling yaitu kelompok 1 yang diberi edukasi melalui audio visual dan kelompok 2 yang diberikan leaflet.

\section{HASIL}

Tabel 1. Karakteristik Remaja

\begin{tabular}{lrrrrr}
\hline \multirow{2}{*}{ Variabel } & \multicolumn{2}{c}{ Intervensi } & \multicolumn{2}{c}{ Kontrol } & p-value* \\
\cline { 2 - 6 } & $\mathbf{n}$ & $\mathbf{\%}$ & \multicolumn{1}{c}{$\mathbf{n}$} & $\mathbf{\%}$ & \\
\hline Jenis kelamin & & & & & \\
Laki-laki & 22 & 55,0 & 20 & 50,0 & 0,823 \\
Perempuan & 18 & 45,0 & 20 & 50,0 & \\
\hline IMT & & & & & \\
Gemuk & 7 & 17,5 & 12 & 30 & 0,293 \\
Obesitas & 33 & 82,5 & 28 & 70 & \\
\hline Umur & & & & & \\
12 tahun & 13 & 32,5 & 9 & 22,5 & \\
13 tahun & 18 & 45,0 & 17 & 42,5 & \\
14 tahun & 9 & 22,5 & 13 & 32,5 & 0,478 \\
15 tahun & 0 & 0 & 1 & 2,5 & \\
\hline
\end{tabular}

Berdasarkan distribusi tabel 1 dengan menggunakan uji chi-square menunjukkan bahwa pada kelompok kontrol dengan presentase laki-laki $50 \%$ dan perempuan yaitu 50\%, sedangkan kelompok intervensi dengan presentase laki-laki 55\% dan perempuan $45 \%$. Sedangkan pada IMT kelompok kontrol dengan presentase gemuk sebanyak 30\%, obesitas $70 \%$ dan presentase pada kelompok intervensi yang gemuk 17,5\% ,obesitas 82\%. Presentase umur pada kelompok kontrol yaitu 12 tahun sebanyak $22,5 \%$, umur 13 tahun $42,5 \%$, umur 14 tahun $32,55 \%$, umur 15 tahun 2,5\% sedangkan untuk kelompok intervensi umur 12 tahun sebanyak $32,5 \%$, umur 13 tahun $45 \%$, umur 14 tahun $22,5 \%$.

\section{Pengaruh Edukasi terhadap Perilaku}

Tabel 2. Pengaruh Edukasi terhadap Pengetahuan

\begin{tabular}{|c|c|c|c|c|c|c|}
\hline \multirow[b]{2}{*}{ Pengetahuan } & \multicolumn{2}{|c|}{ Pre-Test } & \multicolumn{2}{|c|}{ Post-Test } & \multirow[b]{2}{*}{$\Delta \bar{x} \pm \mathbf{S D}$} & \multirow[b]{2}{*}{ p-value } \\
\hline & $\operatorname{Min}-\operatorname{Max}$ & $M e a n \pm S D$ & $\operatorname{Min}-\operatorname{Max}$ & $M e a n \pm S D$ & & \\
\hline Video & $5-10$ & $8,60 \pm 1,482$ & $6-10$ & $9,48 \pm 1,012$ & $1,24 \pm 0,470$ & 0,000 \\
\hline Leaflet & $7-10$ & $8,83 \pm 1,083$ & $5-10$ & $9,42 \pm 0,984$ & $1,41 \pm 1,901$ & 0,003 \\
\hline$\Delta \bar{x} \pm \mathrm{SD}$ & & $0,23 \pm 0,399$ & & $0,6 \pm 1,972$ & & \\
\hline$p$-value & & 0,764 & & 1,000 & & \\
\hline
\end{tabular}

Tabel 2 menunjukan bahwa kelompok kontrol sebelum diberikan leaflet pengetahuan remaja nilai rata-rata atau mean 8,60 dengan standar deviasi 1,482 dan meningkat menjadi 9,48 dengan standar deviasi 1,012 sesudah diberikan leaflet. Hasil uji statistik Wilcoxon pada pengetahuan didapatkan p-value $(0,000)$ atau nilai $p<0,05$ yang artinya ada perbedaan yang bermakna antara pengetahuan remaja sebelum dan sesudah diberikan leaflet. Kelompok intervensi menunjukan bahwa sebelum diberikan video pengetahuan remaja nilai rata-rata atau mean 8,83 dengan standar deviasi 1,083 dan meningkat menjadi 9,42 dengan standar deviasi 0,984 sesudah diberikan video. Hasil uji statistik Wilcoxon pada pengetahuan didapatkan p-value $(0,003)$ atau nilai $p<0,05$ yang artinya ada perbedaan yang bermakna antara pengetahuan remaja sebelum dan sesudah diberikan video. 
Tabel 3. Pengaruh Edukasi terhadap Sikap

\begin{tabular}{|c|c|c|c|c|c|c|}
\hline \multirow[b]{2}{*}{ Sikap } & \multicolumn{2}{|c|}{ Pre-Test } & \multicolumn{2}{|c|}{ Post-Test } & \multirow[b]{2}{*}{$\Delta \bar{x} \pm \mathrm{SD}$} & \multirow[b]{2}{*}{$p$-value } \\
\hline & Min-Max & Mean $\pm S D$ & Min-Max & Mean $\pm S D$ & & \\
\hline Video & $29-45$ & $36,62 \pm 3,874$ & $35-46$ & $40,38 \pm 2,696$ & $4,24 \pm 1,178$ & 0,000 \\
\hline Leaflet & $27-44$ & $36,45 \pm 3,537$ & $32-48$ & $39,65 \pm 4,136$ & $3,20 \pm 1,401$ & 0,001 \\
\hline$\Delta \bar{x} \pm \mathrm{SD}$ & & $0,17 \pm 0,337$ & & $1,27 \pm 2,560$ & & \\
\hline p-value & & 0,977 & & 0,703 & & \\
\hline
\end{tabular}

Tabel 3 menunjukan kelompok kontrol bahwa sebelum diberikan leaflet sikap remaja dengan nilai mean 36,62 dengan standar deviasi 3,874 terjadi peningkatan menjadi 40,38 dengan standar deviasi 2,696 sesudah diberikan leaflet. Berdasarkan hasil uji statistik Wilcoxon rank test pada sikap didapatkan $p$-value $(0,000)$ atau nilai $p<0,05$ yang artinya ada perbedaan bermakna antara sikap remaja sesudah dan sebelum di berikan edukasi melalui leaflet.

Kelompok intervensi menunjukan bahwa sebelum diberikan media audio visual sikap remaja dengan nilai mean 36,45 dengan standar deviasi 3,537 terjadi peningkatan menjadi 39,65 dengan standar deviasi 4,136 sesudah diberikan media audio visual. Berdasarkan hasil uji statistik Wilcoxon rank test pada sikap didapatkan $p$ value $(0,000)$ atau nilai $p<0,05$ yang artinya ada perbedaan bermakna antara sikap remaja sesudah dan sebelum di berikan edukasi melalui media audio visual.

Berdasarkan tabel di atas yang telah di uji melalui uji statistik wilcoxon rank test menunjukkan bahwa ada perbedaan pengetahuan dan sikap antara sebelum dan sesudah di berikan edukasi. Setelah di uji melalui uji statistik mann whitney tidak ada perbedaan yang signifikan antara edukasi menggunakan kelompok media video dan pada kelompok leaflet.

\section{PEMBAHASAN}

Hasil penelitian menunjukan bahwa pengetahuan dan sikap responden meningkat sesudah diberikan leaflet, dilihat dari nilai ratarata sesudah di berikan leaflet yang lebih tinggi dibandingkan dengan nilai rata-rata sebelum di berikan leaflet. Pemberian leaflet dilakukan sebanyak 1 kali dalam semiggu. Variabel pengetahuan diukur 1 kali sebelum diberikan leaflet dan 7 hari sesudah diberikan leaflet. Dilakukan dengan mengisi kuesioner yang diberikan kepada responden pada minggu kedua setelah selesai diberikan leaflet.

Dalam proses edukasi yang dilakukan dengan responden menggunakan leaflet sebagai media edukasi. Leaflet diberikan kepada tiap responden sebagai bahan bacaan dan media pada saat melakukan edukasi. Leaflet yang diberikan kepada responden berisi tentang pengertian overweight dan obesitas, resiko dan penyebab terjadinya overweigt dan obesitas, tipe kegemukan, cara menghitung tingkat obesitas, cara sehat menurunkan berat badan, makanan yang dianjurkan serta piramida gizi seimbang.

Hasil dari kuesioner yang diberikan tentang pengetahuan yaitu ditemukan beberapa responden banyak menjawab salah pada pertanyaaan tentang makanan yang dianjurkan untuk responden yang mengalami kelebihan berat badan. Hal ini dikarenakan kurangnya pengetahuan responden mengenai pemilihan makanan yang tepat untuk di konsumsi.

Hasil uji statistik wilcoxon pada pretest dan postest pengetahuan didapatkan $p$-value $=0,000$ dan sikap 0,000 ini berarti ada pengaruh edukasi dengan media leaflet terhadap pengetahuan dan sikap remaja sebelum dan sesudah diberikan edukasi di SMP IT IQRA' Kota Bengkulu Tahun 2018.

Penelitian ini sejalan dengan penelitian yang dilakukan oleh Saputra,dkk (2016) berdasarkan hasil uji statistik didapatkan $p=0,000$ $(p<0,05)$, yang berarti bahwa ada pengaruh pengetahuan siswa tentang buah dan sayur sebelum dan sesudah diberikan edukasi melalui media leaflet di SMP Al Chasanah dengan nilai rata-rata sebelum edukasi sebesar 8,03 dan nilai rata-rata sesudah edukasi sebesar 10,72.

Penelitian ini sejalan dengan penelitian yang dilakukan oleh Mamonto, dkk (2014) berdasarkan hasil uji statistik didapatkan $p=0,000$ yang berarti $p$-value kurang dari 0,05 , sehingga H0 ditolak. Nilai rata-rata sikap remaja tentang penyakit menular seksual di SMK Fajar Bolaang Mongondow Timur sebelum diberikan pendidikan kesehatan yaitu 4,61 dan setelah diberikan pendidikan kesehatan, nilai rata-rata sikap meningkat menjadi 5,73. Dengan demikian dapat dilihat terjadinya peningkatan skor rata-rata sikap remaja setelah pemberian pendidikan kesehatan Ini menunjukkan bahwa pendidikan kesehatan memberikan pengaruh signifikan terhadap sikap remaja tentang penyakit menular 
seksual di SMK Fajar Bolaang Mongondow Timur.

Sikap merupakan reaksi atau respon yang masih tertutup dari seseorang terhadap suatu stimulus atau objek. Sikap belum merupakan suatu tindakan atau aktivitas, akan tetapi merupakan predisposisi tindakan suatu prilaku. Perubahan sikap responden dapat dipengaruhi oleh media (Leaflet) yang digunakan pada saat edukasi berlangsung yang berfungsi sebagai bahan bacaan.

Hasil penelitian menunjukan bahwa pengetahuan responden meningkat sesudah diberikan media audio visual, dilihat dari nilai rata-rata sesudah di berikan media audio visual yang lebih tinggi dibandingkan dengan nilai ratarata sebelum di berikan video, dari hasil sikap nilai rata-rata sesudah di berikan video lebih tinggi dibandingkan nilai sebelum di berikan video. Pemberian media audio visual dilakukan sebanyak 1 kali dalam seminggu. Variabel pengetahuan diukur 1 kali sebelum diberikan media dan keesokan hari nya diberikan edukasi melalui media audio visual setelah 7 hari sesudah diberikan media dilakukan pengisian kuesioner kembali.

Dalam proses edukasi yang dilakukan dengan responden dengan menggunakan video sebagai media edukasi. Video diberikan kepada responden sebagai bahan edukasi. Video yang diberikan kepada responden berisi tentang pengertian overweight dan obesitas, resiko dan penyebab terjadinya overweight dan obesitas, tipe kegemukan, cara menghitung tingkat obesitas, cara sehat menurunkan berat badan, makanan yang dianjurkan serta piramida makanan seimbang.

Hasil dari kuesioner yang diberikan tentang pengetahuan yaitu ditemukan beberapa responden banyak menjawab salah pada pertanyaaan tentang makanan yang dianjurkan untuk responden yang mengalami kelebihan berat badan. Hal ini dikarenakan kurangnya pengetahuan responden mengenai pemilihan makanan yang tepat untuk dikonsumsi.

Hasil uji statistik Wilcoxon rank test pada pre-test dan post-test pengetahuan didapatkan $p$ value 0,003 ini berarti ada pengaruh edukasi melalui media audio visual terhadap pengetahuan dan untuk p-value sikap 0,001 ini berarti ada pengaruh edukasi melalui media audio visual terhadap sikap remaja sebelum dan sesudah diberikan edukasi di SMP Negeri 04 Kota Bengkulu Tahun 2018.

Penelitian ini sejalan dengan penelitian yang di lakukan oleh Saputra dkk (2016), didapatkan $p=0,000(p<0,05)$, yang berarti bahwa ada perbedaan pengetahuan siswa tentang buah dan sayur sebelum dan sesudah diberikan edukasi melalui media video di SMP Al Chasanah, dengan nilai rata-rata sebelum edukasi sebesar 7,72 dan nilai rata-rata sesudah edukasi sebesar 11,31 .

Penelitian ini sejalan dengan penelitian yang dilakukan oleh Putri, dkk (2017) menunjukkan bahwa rata-rata sikap pada kelompok audio visual untuk sebelum edukasi (pre-test) sebesar 28,9 sedangkan untuk post test sebesar 32,2. Berdasarkan hasil tersebut dapat terlihat nilai mean sikap sesudah penyuluhan (post-test) lebih besar dibandingkan pre-test dengan selisih rata-rata sebesar $-3,3$, hasil uji statistik menunjukkan nilai t sebesar $-7,4$ dengan $p$-value 0,00 atau $p$-value $<0,05$. Dari hasil uji tersebut diperoleh adanya perbedaan yang bermakna secara signifikan terhadap tingkat sikap antara pre-test dan post-test.

Pengetahuan (knowledge), sikap (attitude) dan tindakan (practice) merupakan tahapan perubahan perilaku atau pembentukan perilaku. Sebelum seseorang mengadopsi perilaku ia harus tahu terlebih dahulu apa manfaat bagi dirinya. Untuk mewujudkan pengetahuan tersebut, maka individu di stimulus dengan pendidikan kesehatan. Setelah seseorang mengetahui stimulus proses selanjutnya iya akan menilai/bersikap terhadap stimulus tersebut. Oleh sebab itu indikator untuk sikap kesehatan juga sejalan dengan pengetahuan kesehatan. Berdasarkan pembahasan di atas dapat disimpulkan bahwa pemberian edukasi dengan menggunakan media berpengaruh meningkatkan sikap responden (Notoadmodjo, 2012).

Media audio-visual dapat meningkatkan hasil belajar karena melibatkan imajinasi dan meningkatkan motivasi belajar siswa. Penggunaan media dalam pembelajaran sangat dianjurkan untuk mempertinggi kualitas pembelajaran. Media audio-visual mendorong keinginan untuk mengetahui lebih banyak (Firdaus, 2016).

Media audio-visual tidak saja menghasilkan cara belajar yang efektif dalam waktu yang lebih singkat, akan tetapi apa yang diterima melalui media audio-visual lebih lama dan lebih baik tinggal dalam ingatan. Media audio-visual mempermudah orang menyampaikan dan menerima pelajaran atau informasi serta dapat menghindarkan salah pengertian. Perhatian yang semakin meluas dalam penggunaan media audio visual telah mendorong bagi diadakannya banyak penyelidikan ilmiah mengenai tempat dan nilai media audio-visual tersebut dalam pendidikan. 
Penyelidikan itu telah membuktikan bahwa media audio-visual jelas mempunyai nilai yang berharga dalam bidang pendidikan (Firdaus, 2016).

Selain media audio visual, leaflet juga sangat efektif untuk menyampaikan pesan-pesan secara sistematis, singkat dan padat dalam bentuk baik tulisan maupun gambar (biasanya lebih banyak tulisan). Media ini sangat efektif (dapat dibaca berulang-ulang) untuk menyampaikan pesan yang sistematis, singkat dan padat (Notoatmodjo, 2012).

Machfoedz (2010) menjelaskan bahwa pemberian informasi secara formal maupun nonformal dapat meningkatkan pengetahuan. Salah satu pemberian informasi non formal yang sering digunakan dalam pendidikan kesehatan adalah media leaflet. Leaflet merupakan selembar kertas yang dilipat-lipat, berisi tulisan cetak dan beberapa gambar tertentu tentang suatu topik khusus untuk sasaran dan tujuan tertentu. Media leaflet dapat diperoleh dengan mudah serta efektif digunakan sebagai media informasi. Sebagai media informasi, gambar atau foto haruslah dipilih atau digunakan sesuai dengan tujuan yang telah ditetapkan, dengan adanya gambar atau foto dapat membangkitkan motivasi dan minat untuk membantu menafsirkan serta mengingat pesan yang berkenaan dengan gambar atau foto-foto tersebut (Suarningsih, 2017).

\section{DAFTAR PUSTAKA}

Ali, W., Onibala, R., Bataha, Y.. 2017. Perbedaan Anak Usia Remaja Yang Obesitas Dan Tidak Obesitas Terhadap Kualitas Tidur Di SMP Negeri 8 Manado. Indonesia. EJournal Keperawatan (E-Kp) Volume 5 Nomor 1:1-8

Firdaus A., Sukarno A., dan Sary RM. 2016. Penerapan Media Audio Visual Pada Hasil Belajar Matematika Materi Operasi Hitung Campuran Kelas IV SD Negeri 02 Doro. Prodising Seminar Nasional Universitas PGRI Semarang, FIP. http://prosiding.upgris.ac.id/index.php/fip_ 2016/fip_2016/paper/view/1392

Hasdianah, H. R., dkk. 2014. Pemanfaatan Gizi, Diet dan Obesitas. Yogyakarta: Nuha Medika

Harikedua, V. T. Dan Tando, N. M. 2012. Aktivitas Fisik Dan Pola Makan Dengan Obesitas Sentral Pada Tokoh Agama Di Kota Manado. Indonesia. Jurnal Gizido, Volume 4 No. 1:1-10

\section{SIMPULAN}

1. Karakteristik kelompok intervensi dan kontrol sama dalam proporsi jenis kelamin, Indeks Massa Tubuh dan Umur.

2. Ada pengaruh edukasi melalui media audio visual dan leaflet terhadap peningkatan pengetahuan remaja overweight dan Obesitas.

3. Ada pengaruh edukasi melalui media audio visual dan leaflet terhadap peningkatan sikap remaja overweight dan Obesitas.

\section{SARAN}

1. Bagi pihak sekolah agar dapat menggunakan media audio visual dan leaflet sebagai media untuk melakukan edukasi mengenai gizi kepada siswa-siswi yang ada di sekolah.

2. Bagi siswa-siswi agar dapat mengaplikasikan dikehidupan sehari-hari dan saling mengingatkan sesama teman agar menurunkan berat badan serta hidup sehat.

3. Bagi peneliti selanjutnya bisa menggunakan metode edukasi dengan konseling melalui media booklet yang digunakan agar informasi yang akan disampaikan dapat diterima dengan mudah sehingga dapat meningkatkan pengetahuan, sikap remaja overweight.

Hendra, Cristine., Menampiring, E. A., Budiarso, F.. 2016. Faktor-faktor Resiko terhadap Obesitas pada Remaja di Kota Belitung. Indonesia. E-Biomedik (E-Ebm) Volume 4 Nomor 1:1-5

Indrati, R., dkk. 2014. Pendidikan Konsumsi Pangan. Jakarta: PT. Fajar Interpratama Mandiri.

Kementerian Kesehatan. 2010. Riset Kesehatan Dasar 2010. Jakarta: Badan Penelitian Dan Pengembangan Kesehatan.

Kementerian Kesehatan. 2013. Riset Kesehatan Dasar 2013. Jakarta: Badan Penelitian Dan Pengembangan Kesehatan.

Kussoy, K., Fatimawali.,Kapel, B., 2013. Prevalensi Obesitas Pada Remaja Di Kabupaten Minahasa. Jurnal E-Biomedik (Ebm), Volume 1, Nomor 2:981-985

Mahnun, N. 2012. Media Pembelajaran (Kajian Terhadap Langkah-Langkah Pemilihan Media Dan Implementasinya Dalam Pembelajaran). Indonesia. Jurnal 
Pemikiran Islam, Volume 37, Nomor 1:2733.

Machfoedz, M. 2010. Komunikasi Pemasaran Modern. Cetakan Pertama. Yogyakarta: Cakra Ilmu.

Mamonto, S. F., Rompas, S., \& Karundeng, M. 2014. Pengaruh Pendidikan Kesehatan Terhadap Tingkat Pengetahuan Dan Sikap Remaja Tentang Penyakit Menular Seksual Di Smk Fajar Bolaang Mongondow Timur. JURNAL KEPERAWATAN, 2(2).

Notoatmodjo, S. 2012. Promosi Kesehatan Dan Prilaku Kesehatan. Jakarta: PT. RINEKA CIPTA

Oktira, Y. S., Ardipal, A., \& Toruan, J. L. 2013. Penggunaan Media Audio Visual untuk Meningkatkan Kemandirian Siswa Belajar Seni Budaya. Jurnal Sendratasik, 2(1), 6372 .

Primavera, I. R. C., Suwarna, I. P. 2014. Pengaruh Media Audio-Visual (Video) Terhadap Hasil Belajar Siswa Kelas IX Pada Konsep Elastisitas. Jakarta. Prosiding Seminar Nasional IPA FITK UIN, 11 September 2014.

Putri, T. A. 2017. Efektifitas Media Audio Visual Dan Leaflet Terhadap Peningkatan Pengetahuan Dan Sikap Dan Tindakan Tentang Pencegahan Penyakit Gastritis Pada Santriwati Di Pondok Pesantren Hidayatullah Putrid Dan Ummusshabri Kota Kendari Tahun 2017. Jurnal Ilmiah Mahasiswa Kesehatan Masyarakat Volume 2 Nomor 6.
Rezkina, E., Agustin, C.A. 2015. Metabolisme Zat Gizi. Jakarta: EGC.

Safitri, N.R.D. 2016. Pengaruh Edukasi Gizi Dengan Ceramah Dan Booklet Terhadap Peningkatan Pengetahuan Dan Sikap Gizi Remaja Overweight. [Artikel Penelitian]. Semarang: Program Studi Ilmu Gizi Fakultas Kedokteran Universitas Diponegoro.

Saputra, D. M., dkk. 2016. Pengaruh Pemberian Edukasi Gizi Melalui Media Video Dan Leaflet Terhadap Perubahan Konsumsi Buah Dan Sayur Pada Siswa SMP AL CHASANAH Tahun 2016. [Skripsi]. Jakarta: Program Studi Ilmu Gizi, Fakultas Ilmu-Ilmu Kesehatan Universitas Esa Unggul.

Suarningsih, N.K., Suyasa., Rismawan, M. 2017. Pengaruh Pendididkan Kesehatan Menggunakan Media Leaflet Terhadap Pengetahuan Orang Tua. Jurnal Pengaruh Pendididkan Kesehatan, Vol .01 No. 01: 816

Suryaputra, K., dan Nadhiroh, R.S. 2012. Perbedaan Pola Makan Dan Aktivitas Fisik Antara Remaja Obesitas Dengan Non Obesitas. Jurnal Kesehatan, Vol. 16, NO. 1: 45-50

WHO, 2006. Obesity: Preventing And Managing The Global Epidemic. Report Of A WHO consulation (WHO Technical Report Series 894). 